\title{
Maria Marta Urlińska, Katarzyna Jurzysta: Pomiędzy nadzieja a (nie)spetnieniem. Rola polskiego nauczyciela na Lotwie Toruń 2016, UMK, ss. 381
}

Chciałbym na wstępie podkreślić i zwrócić uwagę na podjęcie w monografii ważnej i złożonej problematyki funkcjonowania szkół polskich i polskiego nauczyciela poza krajem, ze szczególnym podkreśleniem zachodzących zmian, które zostały zaprezentowane w pracy, rodzących się problemów i poszukiwania rozwiązań. Problem ten jest szczególnym wyzwaniem edukacyjnym naszego państwa, także państw Unii Europejskiej, i w tym kontekście niniejsza monografia jest godna uwagi i polecenia. To, co zasługuje na szczególne podkreślenie, to przedstawienie istotnych problemów polityki łotewskiej i rządu polskiego oraz liczne dylematy realizacji zadań przez nauczyciela w kontekście niejasnych, zmieniających się i zróżnicowanych oczekiwań. Autorki monografii podjęły trud przedstawienia funkcjonowania szkół polskich od chwili powstawania, poprzez czas rozkwitu i do czasu powstawania coraz większej liczby pytań o sens ich funkcjonowania, aż do likwidacji niektórych z nich.

Książkę autorki poświęcają profesorowi Zbigniewowi Kwiecińskiemu w podziękowaniu za jego przykład, jak być twórczym i inspirującym Mistrzem. Środowisko naukowe UMK w Toruniu od 1989 roku aktywnie uczestniczyło w odbudowie polskiego szkolnictwa na Łotwie (wyjazdy nauczycieli, wyposażanie w podręczniki i pomoce naukowe, poszukiwanie sponsorów, wymiana dzieci, letnie szkoły w Polsce itp.). Wiodącą rolę we współpracy od 25 lat podjęła i realizuje profesor Maria Marta Urlińska, przedstawiając koncepcję i powołując m.in. dwujęzyczną szkołę we współpracy z Uniwersytetem Łotewskim.

Struktura pracy jest jasna, logicznie i merytorycznie uzasadniona. Składa się $\mathrm{z}$ wprowadzenia do problematyki, dziewięciu rozdziałów rozbudowanych o podrozdziały, zakończenia, bibliografii, streszczenia w języku angielskim (w sumie 381). Chciałbym podkreślić wysoki stopień uporządkowania treści, jak też doboru obszernej, interdyscyplinarnej literatury.

W monografii czytelnik ma możliwość zapoznania się z administracyjno-prawnymi zagadnieniami związanymi z edukacją Polaków poza granicami naszego kraju. Przedstawiono kraje i liczbę nauczycieli delegowanych w latach 1989-2013 do nauczania języka i kultury polskiej w krajach, w których znajdują się Polacy. Autorki zwracają uwagę, że Łotwa to drugie po Ukrainie państwo, do którego we wskazanych wyżej latach trafiało najwięcej nauczycieli. Przeprowadzono wywiady narracyjne z sześćdziesięcioma nauczycielami, wybierając odpowiednią procedurę prowadzenia badań i analizy wyników. Wynikała ona z przedmiotu badań (sposoby 
doświadczania i interpretowania przez nauczycieli oczekiwań społecznych wobec roli polskiego nauczyciela). Wybór metody fenomenograficznej wynikał z badania świadomości nauczycieli, rozumienia i interpretowania oczekiwań kierowanych do nich. Autorki monografii, odwołując się do literatury przedmiotu, przedstawiły i uzasadniły prowadzenie badań w oparciu o fenomenografię uzupełnioną fenomenologią i hermeneutyką, wskazując na metodę monograficzną, technikę wywiadu pogłębionego, obserwację uczestniczącą.

Po przedstawieniu założeń metodologicznych w pierwszym rozdziale, $\mathrm{w}$ drugim zaprezentowano Łotwę w kontekście historycznym, społecznym, politycznym i kulturowym. Przedstawiono informacje w oparciu o bogatą, interdyscyplinarną literaturę. Podobnie, kolejny rozdział, w którym są informacje o łotewskim systemie edukacyjnym ze wskazaniem na problemy edukacji mniejszości narodowych. Wysoko oceniam następny rozdział ukazujący przemiany szkolnictwa polskiej mniejszości na Łotwie. W pierwszej kolejności wskazano na historyczne uwarunkowania funkcjonowania Polaków na Łotwie, następnie proces rewitalizacji szkolnictwa polskiego po 1989 roku i prawne ramy funkcjonowania szkół polskich, społeczno-polityczny kontekst pracy nauczycieli. Zapoznając się z treściami rozdziałów drugiego, trzeciego i czwartego, wnikliwy czytelnik zauważy zachodzące w bardzo szybkim tempie nieprzewidywalne skutki akulturacji i asymilacji, przewartościowanie wartości w społeczeństwie konsumpcyjnym.

Rozdział piąty Perspektywa teoretyczna badań nad rola nauczyciela zawiera bogaty i wartościowy poznawczo przegląd badań związanych z oczekiwaniami wobec nauczyciela. W podrozdziale drugim przedstawiono kategorię roli społecznej, jej komponenty w ujęciu wielu badaczy z różnych dyscyplin humanistycznych i społecznych. Najwięcej miejsca poświęcono koncepcji indywidualnej roli społecznej D. J. Levinsona, w której podkreśla się strukturalne nakazy roli i osobowościową definicję roli. W kontekście treści rozdziału piątego w kolejnym rozdziale zaprezentowano funkcje szkoły etnicznej wobec dylematów realizacji zadań z nich wynikających. Szczególnie wartościowe poznawczo są kolejne rozdziały ze względu na analizy i interpretacje dokonane przez autorki, odwoływanie się do literatury, porównania, prezentacje wskazań i wniosków. Bardzo interesująco przedstawione zostały motywy decyzji wyjazdu do pracy na Łotwę. Obszerne relacje i ich interpretacja są ważne nie tylko dla władz ministerialnych delegujących nauczycieli, ale przede wszystkim dla pracowników Ośrodka Rozwoju Polskiej Edukacji za Granicą, przygotowujących nauczycieli do pracy z dziećmi i rodzicami pochodzenia polskiego mieszkających poza krajem. Podobnie wartościowe są interpretacje oczekiwań w kontekście pełnionej roli nauczyciela (dyrekcji, pracowników ORPEG, wcześniej CODN, uczniów i rodziców). Problemem jest, tak sądzę, dominacja aksjologii administracyjnej nad aksjologią patriotyczną. Ostatni, dziewiąty rozdział pracy, nosi tytuł Dylematy roli polskiego nauczyciela na Łotwie. Dylematem rzeczywiście jest komunikacja 
społeczna. Może należałoby przywołać Floriana Znanieckiego, dla którego jednym z istotnych problemów była komunikacja międzykulturowa prowadząca do ładu pokojowego, stąd badał możliwości rozwoju solidarności społecznej zorganizowanej wokół wspólnych wartości kultury. Może należałoby poszukiwać takich wspólnych wartości. Przewidywał, że polityka, która nie uwzględni narodu jako solidarnej społeczności, poniesie porażkę. Antagonizm na gruncie różnic kulturowych jest bowiem większym problemem w porównaniu z konfliktem wynikającym ze zwykłej różnicy interesów. W kontekście powyższego odczytywany jest obecnie jego program socjologii edukacji i wychowania, problemy tożsamości narodowej i rozpad tradycyjnych, wspólnotowych form życia społecznego, demokratyczne zmiany społeczne, społeczeństwo obywatelskie i inne problemy interakcji kultur. Może nauczycieli i rodziców należy pytać i ukierunkować rozmowę na takie problemy:

- czy szanując własną kulturę, rozwijając poczucia dumy, wyrażając szacunek do własnego dziedzictwa kulturowego równocześnie wzbogacamy inne kultury?

- czy „zamykając” się tożsamościowo przed ofertami i innymi wizjami życia nie ukierunkowujemy się ku nacjonalizmowi i nie zmierzamy do samounicestwienia kulturowego?

- czy kultura nie dała się uwieść polityce i politykom i czy nie mamy do czynienia obecnie z kulturą upolitycznioną i aksjologią administracyjną?

Dyrektorzy oczekują wysokich wyników, władze administracyjne w Polsce udają, że kierują nauczycieli do krzewienia kultury polskiej, rodzice zdają sobie sprawę z ważności języka państwowego, w domu nie rozmawiają - lub bardzo rzadko - w języku polskim, dzieci nie znają i nie są w stanie rozmawiać w języku polskim, który dla nich jest obcy itd., a więc nauczyciel nie ma prostej drogi aby sprostać zadaniom formalnym i mieć poczucie odpowiedzialności w kontekście pełnionej roli. Może dobrze byłoby w interpretacji odwołać się do pedagogiki kultury - faktu kulturowego w ujęciu Bogdana Nawroczyńskiego. Są fakty społeczne wspólne wielu grupom, które funkcjonują w społeczności i przechodzą w tradycję (porozumienia, dialogu, współpracy, kreowania pokoju itp.). Mogą funkcjonować na kilku poziomach czy piętrach; w sferze materialnej (technika, gospodarka), cywilizacyjnej (życie społeczne, narodowe, państwowe, wartości narodowe, państwa i Kościoła, ruchy promujące mniejszości) oraz w sferze duchowej (nauce, sztuce, literaturze, plastyce, muzyce, religii, ruchy chroniące wartości duchowe). Takie są właśnie w przypadku Łotyszy i Polaków, na co zwracają uwagę autorki monografii. Może problem komunikacji językowej nie jest najważniejszy obecnie w kreującej się tożsamości a terytorium, więzi, wspólnota europejska itp. Współcześnie sentymentalizm nie wystarcza, co wynika z niniejszej pracy, a konieczne jest ustawiczne zastanawianie się:

- jak być patriotą u siebie i w Europie, jak być patriotą jednocześnie w Ojczyźnie prywatnej (patriotyzm lokalny), w kraju (narodowy, państwowy, konstytucyjny, obywatelski), w Europie (cywilizacyjny, kosmopolityczny)? 
- czy możliwe jest: czuć się i realizować lokalnie, regionalnie, narodowo, w danym państwie, w Europie, realizować koncepcję obywatelstwa?

Nikt w obecnych warunkach wielokulturowości nie może być i nie powinien być „zakładnikiem” odziedziczonej kultury, gdyż ustawicznie uczestniczy w interakcjach z reprezentantami innych kultur i w procesie socjalizacji i akulturacji. To autorki ukazały i jednocześnie zwróciły uwagę na szybko zachodzące zmiany, zanik tradycji i bezradność w ich kultywowaniu. Czas szkół - skansenów narodowych wydaje się mijać, a więc należałoby zastanowić się, o jaki rodzaj patriotyzmu nam, Polakom, chodzi w tego typu szkołach (romantyczny, bohaterski, martyrologiczny, narodowy, państwowy, obywatelski, europejski, cywilizacyjny, kosmopolityczny itd.). Z przedstawionych wypowiedzi nauczycieli wyraźnie nie wynika myślenie i świadomość obywatelska (chociaż w pewnych wypowiedziach dało się to zauważyć), która w dużym stopniu jest niezależna od narodowej, etnicznej tożsamości jednostki. Odnosi się do członkostwa we wspólnocie politycznej (państwowej), a nie narodowej (etnicznej czy kulturowej). Istotne jest to, jak kształtować motywację zauważania inności, motywację poznania i zrozumienia, jak na bazie naturalnego patriotyzmu kształtować tolerancję, aby patriotyzm nie zamykał i nie zmierzał ku nacjonalizmowi, ksenofobii, megalomanii, fanatyzmowi itp. Istotne w pracy tych nauczycieli jest przedstawianie osób znaczących w historii Polski i obecnie aby kształtować na tej bazie odpowiedzialność, zaangażowanie, prospołeczność, sumienność i rzetelność w codziennej pracy, umiejętności interpersonalne, empatyczne, twórcze, innowacyjne, postawy samorozwojowe, autorefleksję. Istotna obecnie jest wiedza, refleksyjność w postrzeganiu i rozumieniu problemów współczesnego świata, odpowiedzialność za losy i przyszłość gatunku ludzkiego.

$\mathrm{Z}$ analiz wypowiedzi wynika - może to jest wynikiem zjednoczonej Europy - że rodzicom zależy, aby dzieci znały język państwowy, a ten drugi - polski, jeżeli jest finansowany dodatkowo może się przydać, jednak bardziej istotna jest więź z państwem i obywatelstwo tego państwa. Przecież pojęcie obywatelstwa jest w dużym stopniu niezależne od narodowej, etnicznej tożsamości jednostki. Odnosi się do członkostwa we wspólnocie politycznej (państwowej), a nie narodowej (etnicznej czy kulturowej). Nie można zadekretować prawnie świadomości narodowej czy etnicznej człowieka. Silna identyfikacja z kulturą narodową nie jest w opozycji do zainteresowania innymi kulturami, nabywania otwartej tożsamości kulturowej. Tak postrzegam realizację funkcji etnicznej. Jan Józef Lipski zwracał uwagę, że miłość ojczyzny musi być stale uzupełniana duchowymi wartościami, gdyż czysto etniczna przynależność nie konstruuje jeszcze patriotyzmu. Dopiero w powiązaniu z wolnością i godnością ludzką miłość do własnego kraju nabiera sensu. Stąd problem roli polskiego nauczyciela na Łotwie jest bardzo złożony. Sądzę, że winien być ukierunkowany w kontekście obywatelstwa, które uważam za przejaw transnarodowości i transkulturowości w procesie kreowania paradygmatu współistnienia w nowej, integrującej 
się Europie. Transkulturowa koncepcja kultury i tożsamości Wolfganga Welscha przeciwstawia się substancjalnej koncepcji kultury Johanna Gottfrieda Herdera, która nie odpowiada moim zdaniem już dzisiejszym realiom, gdyż doprowadziła do gettoizacji i fundametalizmu kulturowego. Tego problemu nauczyciele jakby nie dostrzegali, skupiając się na kompetencjach metodycznych, nadawaniu sensu niejasnej i trudnej roli nauczyciela, rozterkach, sprzecznościach itp.

Chciałbym zwrócić uwagę, że w pracy mamy pogłębione analizy i interpretacje, ciekawe i wartościowe poznawczo analizy jakościowe w kontekście zróżnicowanych oczekiwań wobec roli nauczyciela wielu podmiotów. Jestem przekonany, że niniejsza praca może być nie tylko inspiracją dla studentów i nauczycieli do pracy edukacyjnej. Ukazuje ważną kulturowo historię „siłaczek” wspierających dzieci i rodziny pochodzenia polskiego poza granicami naszego kraju. Zawiera ona, moim zdaniem, szczególnie ciepły, emocjonalny obraz zatroskanych nauczycieli, ich decyzje, losy, problemy adaptacji, akulturacji, dylematy tożsamościowe, czyli problemy trudne i ważne w zrozumieniu zmiennego, dynamicznego, nieprzewidywalnego, wielokulturowego świata. To sprawia, że jest źródłem cennych informacji niwelujących stereotypowe postrzeganie szkoły polskiej na obczyźnie i funkcjonującego w niej nauczyciela, który zdecydował się podjąć wielki wysiłek edukacyjny.

Autorki podjęły próbę spojrzenia na polskiego nauczyciela na Łotwie w wielu wymiarach i kontekstach, co w efekcie wzbogaca nas wszystkich i pozwala mieć nadzieję na nieodwracalny, aczkolwiek bardzo trudny, proces kształtowania się społeczeństwa obywatelskiego. Zapoznanie się z niniejszą pracą pozwala mi na wyrażenie przekonania, że edukacja instytucjonalna (szkolna), aby miała sens i osiągnięcia, winna bazować na edukacji rodzinnej, na jej wartościach i zasadachnormach. Dopiero na ich bazie i w oparciu o nie szkoła może otwierać na inne wartości, oferować i przedstawiać je, inaczej będzie to uznawane i traktowane jako zawłaszczanie tożsamościowe, a efekty będą nikłe. Problemem ciągle jest to, czy system edukacyjny danego kraju jest przygotowany na uszanowanie i wzmacnianie odrębności i pierwszej socjalizacji rodzinnej, co pozwala otworzyć się na innych, poznać i lepiej ich zrozumieć.

Reasumując, chciałbym podkreślić wartość poznawczą i metodyczną pracy, wysoki poziom znajomości i różnorodności prezentowanej literatury przedmiotu, jak też umiejętność jej doboru i interpretacji. Poza tym chciałbym zauważyć i wysoko ocenić dokonanie interdyscyplinarnych analiz podjętego problemu, dokonanych porównań, odniesień, wnioskowań. Sądzę, iż przedstawione w monografii pełnione role nauczycieli mogą stymulować jednych do weryfikacji twórczych rozwiązań, innych do doskonalenia i modyfikacji pomysłów, jeszcze innych do ustawicznych poszukiwań, refleksji nad stosowanymi strategiami. 